\title{
LEARNER AUTONOMY: PRACTICES USED AND CHALLENGES ENCOUNTERED BY EFL TEACHERS IN FOSTERING LEARNER AUTONOMY AT TERTIARY LEVEL
}

\author{
Le Van Tuyen*, Huynh Thi An \\ Ho Chi Minh City University of Technology (HUTECH) \\ 475 A Dien Bien Phu Street, Binh Thanh District, Ho Chi Minh City, Vietnam
}

Received 28 May 2019

Revised 29 June 2019; Accepted 28 July 2019

\begin{abstract}
It is undoubted that teacher autonomy (TA) and learner autonomy (LA) are among the factors that affect the effectiveness of English teaching and learning in non-native English speaking contexts like Vietnam. Investigating how teachers and students perceive TA and LA may be considered a valuable addition to the literature. This study, therefore, aimed to explore students' perceptions of teachers' practices used to foster LA and teachers' perceptions of challenges they may encounter in fostering LA in EFL classes at Ho Chi Minh City University of Technology (HUTECH)-Vietnam. Two instruments were employed to collect both qualitative and quantitative data, namely the questionnaire and interview with the participation of 12 EFL teachers and 160 first-year English majored students. The findings of the study revealed that most of the EFL teachers who taught the first-year students used practices through responsibility-informing and in-class activities to foster LA. However, the findings also indicated that the teachers encountered several challenges related to students, teachers and the context. It is expected that the findings of the study would partly contribute to the enhancement of TA and LA in English language education at HUTECH in particular and at the Vietnamese tertiary level in general.
\end{abstract}

Keywords: teacher autonomy, learner autonomy, practices, challenges, Vietnamese tertiary level

\section{Introduction}

Over the past thirty years the idea of autonomy in language learning has developed. This idea is represented as a learner-centered idea (Benson, 2008). It has increasingly impacted the field of language education, especially foreign language education in contexts like Vietnam where traditional methods and teacher-centered paradigm had been the focus for long, and where it is assumed that now TA and LA play an important role in the process of teaching and learning. The shift from teachercentered paradigm to student-centered one has put much pressure on both teachers and

* $\quad$ Corresponding author. Tel. 84-982362727

Email: 1v.tuyen@hutech.edu.vn students. In addition, changing concepts about teachers' and students' role is a must. No longer do teachers only play the role of a knowledge conveyer. Instead, they should employ different strategies and play different roles to facilitate students' process of learning. They should train their students how to learn. They have to shift their roles to facilitators, gap-fillers or co-learners. Especially, teachers should act as promoters of autonomous learning among students. Doing so will certainly make great contributions to the development of LA. Similarly, students no longer act as passive knowledge receivers. Language knowledge and skills will be more easily acquired for those students who do not rely too much on their teachers and for those who have intrinsic motivation (Brown, 2002). 
So far many studies have been conducted to investigate issues related to TA and LA such as the dependence of LA on TA (Little, 1995); the relationship between TA and workplace (Pearson \& Moomaw, 2005); fostering TA in the use of materials (Ling, 2007); teacher education and TA (Benson, 2010); teaching for LA (Feryok, 2013); teachers' role in developing LA (Xu, 2015); teacher development for autonomy (Vázquez, 2016), and many others. In the Vietnamese context, several studies have been conducted in relation to LA on curriculum for EFL students (Trinh, Q. L., 2005); self-initiation and self-regulation in Writing (Nguyen T. C. L., 2009); students' perceptions and performances of LA (Dang T.T., 2012); students' belief about and performance of LA (Le X. Q., 2013); EFL teachers' beliefs about LA (Nguyen T. N., 2014); factors affecting LA in learning writing (Tran T.T. \& Duong M. T., 2018) and EFL students' voices on LA (Le T. N. A., 2018). Nonetheless, little literature related to English teachers' practices and challenges in fostering LA at tertiary level in Vietnam has been found. To contribute partly to the existing knowledge of TA and LA in teaching and learning foreign languages in the context, this study, therefore, aims to explore (1) practices used by EFL teachers in fostering first-year English majored students' autonomy at Ho Chi Minh City University of Technology (HUTECH) and (2) challenges that EFL teachers encounter in doing the above task. The two aspects explored in this paper are considered to be of primary concern and in need of in-depth focus. The study attempted to address the two following research questions:

1. How do first-year English majored students perceive EFL teachers' practices in fostering learner autonomy?

2. What are the challenges that EFL teachers encounter in fostering learner autonomy?

\section{Literature Review}

\subsection{Learner Autonomy}

New insights into learning a foreign language have considerably increased the demand for LA, and recently theory and practice of LA has developed remarkably (Teng, 2019). The term LA was first defined by Holec (1981) as "the ability to take charge of one's own learning”. Later, various terms concerning LA have been used by researchers such as self-instruction which means students can teach themselves, self-regulation which means students can control their behaviors in the pursuit of learning goals, independent learning, self-access learning, or self-directed learning (Teng, 2019). Based on Holec's definition of autonomy, it can be interpreted that autonomous students are expected to be responsible for their learning. They have to actively participate in learning, take charge of self-planning, self-management, selfreflection and self-evaluation (Teng, 2019), and make use of their ability both in skills and knowledge in learning and in the language. Autonomous learning also requires students to have desire to learn a language or carry out learning tasks with particular purposes and to control their learning in a certain learning context (Benson, 2011). Autonomous students determine the objectives, define the contents, select appropriate learning methods and techniques, monitor the procedure of acquisition, and evaluate what has been learned. When attempting to perform the above tasks, they need to be metacognitively aware of this process. Being aware of the learning process, it is required that they have knowledge, goals and strategies utilized to achieve specified goals. They should have belief in themselves as learners (Little, 1995; Benson, 2011; Teng, 2019). Autonomous learning also manifests students' degree 
of motivation, including instrumental motivation which refers to the need to fulfill the practical objectives of learning a language and integrative motivation which refers to the need to identify with the target language (Bension, 2011; Teng, 2019).

Obviously, the terms LA encompasses different interpretations. Nonetheless, it cannot be interpreted that students are independent of their teachers, or their learning is completely isolated from teachers' roles and practices, and from the learning environment and the institution.

\subsection{The role of EFL teachers in fostering learner autonomy}

The role of EFL teachers in fostering LA in this paper is seen from the perspective of Macaro's (2008) model of autonomy. Accordingly, autonomy in language learning manifests three dimensions: autonomy of language competence (ALC), autonomy of choice (AC), and autonomy of language learning competence (ALLC) (Macaro, 2008). The three dimensions seem to be closely related to each other. Regarding ALC, Macaro (2008) emphasizes that L2 students should have the ability to communicate appropriately in a particular L2 situation and generate their own sentences or utterances. Obviously, every time students want to say or write something they must rely on what they have learned, which is the language input from their teachers. In respect of $\mathrm{AC}$, researchers have indicated that learning something new requires students to be directed by goals or purposes. According to Locke (1996), for goals to be achieved effectively, they should be set through the free choice and commitment of the individual student. Goals must be specific, explicit and attainable. Goal commitment is considered to be particularly important (Macaro, 2008). Commitment to a goal influences performance by (a) directing attention and effort towards goal relevant tasks; (b) adjusting the effort to the level of difficulty required by the task; (c) encouraging persistence until the task is achieved; (d) supporting the development of appropriate action plans and strategies. Goals also provide the standards for the evaluation of students' performance, and attainable goals have an important function in the development of self-efficacy. In a formal educational setting, all the above aspects which are related to goal setting and commitment need support from the teacher. Another element which is essential for the development of LA is the choice of materials. Students have to decide which materials they need to refer to, for example, outside the class. Selecting learnercentered materials to foster LA cannot be done by students themselves. It is necessary that teachers know how to evaluate, analyze, and even produce materials (Reinders \& Lewis, 2008) to meet the student's goals.

In terms of ALLC, Macaro (2008) indicates that it is the ability to use a range and combination of cognitive and metacognitive strategies. This task can be achieved with the support of the teacher's approaches, and later independently of the teacher's approaches and techniques. Another aspect relating to ALLC is the learning environment to develop the experience, the confidence and the systematic application of metacognitive awareness. Whether or not the learning environment for students to experience learning strategies is created depends on the teacher. LA, when seen from this perspective, is far from being a withdrawal by the teacher (Macaro, 2008). On the contrary, there is a close relationship between the teacher and students in finding a pathway to develop ALC, AC and ALLC. Based on the three above mentioned dimensions of LA, it can be confirmed that students need support to develop language competence themselves; 
they should be provided with opportunities to develop autonomy in choosing what materials and learning strategies are best for their learning. In addition, autonomous students should have the awareness, the knowledge and the experience of strategy use, and the metacognition to evaluate the effectiveness of those strategies. This leads to the fact that when seen from this perspective teachers cannot be the outsider in the development of LA.

Other researchers and educators have also raised their points of view about this aspect. Little (1995) contends that LA and TA are 'interdependent'; and almost all students need to be prepared and supported on the path towards greater autonomy by teachers (Sheerin, 1997); and LA does not mean learning in isolation; instead, it needs teachers' and others' support (Esch, 1997). In addition, to help students become autonomous, teachers have to be autonomous and have beliefs about what autonomy is (Thavenius, 1999). Especially, according to Jing (2007), TA is now recognized as a major factor that affects the development of LA in second language learning; and that is why there is always a close link between TA and LA (Lamb, 2008). LA can also be cultivated and explored in the classroom with the help of TA (Yan, 2010). TA and LA are interrelated and interactive. Developing autonomy in formal situations cannot take place without teachers' engagement (Klimas, 2017). LA is an achievement which can be attained interrelationally between students and teachers. It depends upon how teachers and students relate to each other on their capacities to develop their relationship in ways conducive to LA (Ganza, 2008).

Based on the three dimensions of LA stated by Macaro (2008), it can be interpreted that to enhance LA, we must have autonomous teachers in both professional development and action. EFL teachers should be responsible to foster students' ALC, AC, and ALLC. Nonetheless, the current study only focused on practices which EFL teachers used to foster ALLC among first-year English majored students. An autonomous teacher with autonomous students will make an autonomous language class.

\subsection{Practices and challenges in fostering learner autonomy}

The process of language acquisition requires students to be active, autonomous and later independent in their learning. They need teachers' collaboration and support to gain some levels of autonomy (Ramos, 2006). Teachers' use of practices to promote their teaching practices in class may have a close relationship with the development of LA (Dikilitaş \& Griffiths, 2017). Dam (2003) and Little (1999) emphasize that teachers are required to be involved in a variety of activities. They are responsible for communicating expectations, such as learning objectives or task requirements. They should provide students with appropriate activities and allow students to have choice in organizing work so that students will be able to reach previously assigned goals as well as their personal goals. Teachers should raise students' awareness of all the elements of the learning process by initiating and encouraging discussions among learners as well as between the teacher and students. To put it specifically, such tasks that were suggested by researchers (Little, 1999; Dam, 2003; Little, 2004; AgustínLlach \& Alonso, 2017; Klimas, 2017) are creating conditions for students to involve in the development of autonomy, for example, encouraging them to plan, or set up long-term and short-term learning objectives, providing them with skills and strategies so that they can learn by themselves; providing them with 
tools or techniques for reflecting what they have learned or giving them advice on how to solve difficulties through conversations. In class, appropriate target language use must be the focus. Teachers help students to enhance autonomy through appropriate learning activities, classroom arrangement and positive attitudes towards students' different learning styles and preferences. In addition, using the target language not only takes place in class. It is the teacher's responsibility to encourage students to use the target language outside class through the introduction of materials and tools that can be used to improve their target language.

Nonetheless, teachers may encounter challenges when fulfilling the above tasks. Borg and Al-Busaidi (2012) indicate that teachers may encounter many challenges in their efforts of promoting their students to become autonomous in language learning. Those challenges may be the teachers themselves. Teachers may lack autonomy; they themselves were not autonomous when they were students so now they lack experience in training LA. Or even teachers' limited expectations of what learners can achieve. Other challenges that teachers may face may be related to students. One of the most challenges may be students' limited proficiency in English of lack of incentive, ability and skills to exploit resources or learning strategies. Teaching and learning in formal education must take place in an institution. Therefore, the institution or the learning environment may also cause teachers challenges in the process of enhancing LA. For instance, so much pressure may be placed on teachers. They are always overwhelmed and overloaded with work; and how can they be autonomous in their professional development and practice? It may be also because of prescribed curricula and materials or lack of relevant resources for both teachers and students such as webs, the Internet, videos, and many other things (Alibakhshi, 2015). It can be concluded that challenges that teachers may encounter in fostering LA may related to three major factors: teachers, students, and the context.

The above-mentioned tasks reflect the three interdependent pedagogical principles that guide fostering LA (Dam, 2003; Little, 2004), namely (a) learner involvementteachers should create appropriate conditions for students and encourage them to become personally and collectively responsible and more involved in learning; (b) learner reflection-teachers should stimulate students to apply critical thinking to planning, monitoring and evaluating their learning; and (c) appropriate target language use- teachers should direct interaction among students in such a way so as to exploit their language potential. With the aim of investigating practices used and challenges encountered by EFL teachers in fostering LA, the above three principles of fostering LA and the three major challenges relating to teachers, students and the context indicated by Borg and AlBusaidi (2012) are chosen as the theoretical framework for the current study.

\section{Research Methodology}

\subsection{Participants}

This study was conducted at Ho Chi Minh City University of Technology (HUTECH) in Ho Chi Minh City, Vietnam. The participants of the current study consisted of (a) 12 EFL teachers who taught first-year English classes. 11 of them had M.A degrees and 1 had Ph.D. 9 of them are female $(75 \%)$, and 3 are male $(25 \%)$; and all of them had more than three years of teaching experience. Their ages 
ranged from 26-29 (4 teachers), 30-35 (6 teachers) to 41-over (12 teachers); and (b) 160 students who were studying English as a major in the first academic year at HUTECH. 123 of them are female (77\%); and 37 of them are male $(23 \%)$. Their ages range from 19 to 20 .

\subsection{Instruments}

Two instruments were employed in this study, namely the closed-ended questionnaire and the semi-structured interview. The student questionnaire consisting of 17 items was used to explore students' perceptions of their teachers' practices used to foster LA in terms of practices through responsibility-informing activities and practices through classroom activities (Urun, Demir \& Akar, 2014). The questionnaire used five-point Likert scale ranging from Never, Rarely, Sometimes, Often and Always. Based on calculated interval coefficient for four intervals in five points (5$1=4)$, intervals with the range of $0.80(4 / 5)$ were arranged. The following criteria in the Likert type scale were used to interpret the data: never (1.00 - 1.80); rarely (1.81 - 2.60); sometimes $(2.61-3.40)$; often $(3.41-4.20)$; always (4.21 - 5.00).

Regarding the questionnaire for the teachers, it consisted of 19 items; the first 4 items were used to explore demographic information of the teachers; the 15 remaining items were used to explore teachers' challenges in fostering LA in terms of teacher-, studentand context-related challenges. To avoid neutral option, the questionnaire used fourpoint Likert scale ranging from Strongly Disagrees, Disagree, Agree to Strongly Agree. Based on calculated interval coefficient for three intervals in four points $(4-1=3)$, the intervals with the range of $0.75(3 / 4)$ were arranged. The following criteria in the Likert type scale were used to interpret the data: strongly disagree (1.00 - 1.75); disagree (1.76 $2.50)$; agree (2.51 - 3.25); strongly agree (3.26 - 4.00). The reliability of both questionnaire was tested through Cronbach's Alpha with the coefficient of .693 (teacher questionnaire) and .848 (student questionnaire) which proved that the questionnaires were acceptably reliable.

The semi-structured interview was used to obtain more insight from the students' perspectives about the teachers' practices in fostering LA in English language classes, and from teachers' perspectives about challenges they encountered in fostering LA. For convenience reasons, both the questionnaire items and interview questions for the students designed in Vietnamese and later translated into English.

\subsection{Data collection and analysis}

Regarding data collection procedure, firstly, to collect data from the teacher participants, questionnaire copies were administered to 14 teachers. A week later, however, 12 of them returned the questionnaire copies, accounting for $86 \%$. Later, 3 teachers (among 12) were randomly selected to participate in the interview.

Secondly, to collect data from student participants, it was on $9^{\text {th }}$ March, 2019 when the English Language Faculty organized a meeting for first-year English majored students, one of the researchers came to the meeting to introduce the purpose and significance of the study. Then, the questionnaire was administered to 170 students; and the instruction how to complete the questionnaire was clarified and explained carefully to them. The students were asked to complete the questionnaire and return them in the following week. After a week, 160 students returned the questionnaire, accounting for 94\%. Later, 10 among 160 students were invited to participate in the interview sessions. 
Those 10 students were class monitors. The researcher took notes of the responses. Each interview lasted almost 15 minutes.

Regarding data analysis, to analyze the data obtained from the questionnaire, SPSS 20.0 was employed so that descriptive statistics including Percentage, Mean (M), Standard Deviation (St. D) were processed, whereas content analysis was employed to deal with qualitative data; and the students were coded as S1...to S10 and the teachers were coded as T1, T2 and T3.

\section{Results and Discussion}

\subsection{Teachers' Practices in Fostering LA}

The results of Research question 1 presented and interpreted below are based on two categories, namely practices through responsibility-informing activities and practices through classroom activities.

\subsubsection{Practices through responsibility-} informing activities

The data displayed in Table 1 revealed that the teachers often employed practices to inform their students of their responsibility in the development of LA. More specifically, regarding objective-setting practices, the teachers helped the students set up their own long-term and short-term learning objectives (item 1) with $\mathrm{M}=3.54$, encouraged them to make plans for learning (item 2) with $\mathrm{M}=3.59$. In terms of strategy-identifying practices, the students perceived that the teachers often provided them with the skills and strategies they needed to learn on their own (item 3) with $\mathrm{M}=3.80$. In addition, having beliefs of the importance of materials that students should use outside the classroom, the teachers not only often encouraged them to read English books, magazines, and newspapers, but they also suggested websites, and videos that could be used to practice the target language (item $4 \& 5$ ) with $\mathrm{M}=3.77$ and 3.77 respectively. More interestingly, the students were usually encouraged to do assignments or prepare projects before coming to class (item 6) with $\mathrm{M}=4.02$. However, regarding reflectionsupporting practices, the students perceived that the teachers only sometimes suggested tools and techniques for self-assessment or showed them how to evaluate their own learning progress (items $7 \& 8$ ) with $\mathrm{M}=3.21$ and 3.35 respectively.

Similarly, all the ten interviewed students $(100 \%)$ reported that they received encouragement from the teachers in making learning plans, and setting goals and objectives. For example:

S8 reported, "My teachers usually show me techniques to study by myself. They help me to make learning objectives and organized activities for us to work in pairs or in groups."

In addition, $90 \%$ of the interviewed students revealed that during the lessons the teachers used different strategies in teaching the four language skills and language knowledge. Through the classroom activities, the teachers showed them how to self-study at home. For example:

S6 expressed, "In this semester we learn writing 1 and reading 2 . The teachers ask us to do different activities and show us how to do the activities so I learn a lot, both language and the ways how to learn."

Regarding the materials used outside the classroom, all the participants reported that their teachers introduced grammar, writing and reading books to them so that they could learn by themselves. However, according to the students, they would like the teachers to provide them with the materials, not only introduce because they could not afford or find them. More interestingly, all of the ten 
students $(100 \%)$ said that after each class, the teachers gave them assignments to do at home. They were encouraged to prepare presentations for the next lesson. They were asked to do exercises of vocabulary and grammar in the textbook. For example:

S3 expressed, "We not only take part in class activities, but we have to do assignments at home. My writing teacher encourages us to practice writing at home because in class we do not have enough time; or my speaking teacher asks us to prepare ideas about the topic she gives us for next classes."

However, regarding tools and techniques for self-assessment and evaluating learning process, only $40 \%$ of the interviewed students reported that they were shown how to assess their learning. They were asked to keep portfolios or have an exercise notebook. The other students revealed that they did not know how to evaluate their learning. The teachers rarely provided feedback, so they did not know whether they did their assignments correctly or not. For example:

"Self-learning does not mean that we can do everything. We need the teacher to show us how to learn and how to assess ourselves. Sometimes after writing some sentences, we don't know they are right or wrong. We need some help from the teacher (S7)."

This finding is consistent with that from the questionnaire that the teachers sometimes showed the students the way how to do selfassessment.

Table 1: Practices through responsibility-informing activities

\begin{tabular}{|c|c|c|c|}
\hline No. & Items & \multicolumn{2}{|c|}{ N= 160 } \\
\cline { 3 - 4 } & M & St.D \\
\hline 1 & $\begin{array}{c}\text { Your teachers help you to set up your own long-term and short-term } \\
\text { learning objectives. }\end{array}$ & 3.54 & .815 \\
\hline 2 & Your teachers encourage you to make plans for studying. & 3.59 & .900 \\
\hline 3 & $\begin{array}{c}\text { Your teachers tell you the skills and strategies you need to learn on your } \\
\text { own. }\end{array}$ & 3.80 & .853 \\
\hline 4 & $\begin{array}{c}\text { Your teachers encourage you to read English books, magazines, and } \\
\text { newspapers outside class. }\end{array}$ & 3.77 & .933 \\
\hline 5 & $\begin{array}{c}\text { Your teachers suggest materials, websites, videos and other tools that } \\
\text { you can use to practice English outside class. }\end{array}$ & 3.77 & .899 \\
\hline 6 & $\begin{array}{c}\text { Your teachers encourage you to do assignments or projects outside } \\
\text { class. }\end{array}$ & 4.02 & 1.067 \\
\hline 7 & Your teachers introduce tools and techniques for your self-assessment. & 3.21 & 1.036 \\
\hline 8 & Your teachers show you how to evaluate your own learning progress. & 3.35 & 1.089 \\
\hline
\end{tabular}

The findings of the study revealed that most of the first-year English majored students were satisfied with their teachers' responsibility-informing activities. Although the teachers only sometimes suggested tools or techniques for self-assessment or supported the students in evaluating their learning process, it can be said that teachers were responsible for informing the students of strategies they needed to develop LA. The findings proved that the English teachers were aware of the importance of fostering students in planning, monitoring and evaluating their learning. They knew that guidance and support are integral elements of learning, and that without interaction of some kind autonomy is unlikely to develop (Palfreyman, 2018). Moreover, knowing how 
to select relevant learning resources is highly related to knowing one's needs (Chik, 2018). However, realizing that it is not easy for the first-year students to have competence to do this task, the teachers lent the students a regular helping hand to stay afloat (Sheerin, 1997). Autonomy results from targeted strategy training (Sinclair, 2008). It can be seen that the English teachers provided the students with the strategies and techniques for learning English outside class without the presence of the teacher. The teachers were willing to take responsibility for their instruction and their students' learning.

The findings of the study also implied that, to develop LA, the first-year students needed the teachers to make them aware of the learning goals, content and strategies underlying the materials they were using. They needed to identify strategy implications of pedagogical tasks and their own preferred learning styles and strategies (Nunan,1997; Sheerin, 1997). In addition, they wanted the teachers to encourage them to work in groups or pairs to develop their own ideas. They wanted to be challenged to think for themselves (Smith, Kuchah \& Lamb, 2018).

It is undeniable that the English teachers have changed their roles in the classroom. They have not been seen as the ultimate authority and the maker of all the decisions related to learning. Instead, they had beliefs about the importance of responsibilities in teaching and learning held by both students and teachers as Lamb (2008) stated. The findings of the study were consistent with those of the study conducted by Urun, Demir and Akar (2014) that revealed that English teachers used responsibility-informing activities to develop LA.

\subsubsection{Practices through in-class activities}

The data displayed in Table 2 shows that the English teachers used practices through in-class activities to foster LA. Although the frequency was not very high, it is confirmed that the teachers quite often organized various types of learning activities or tasks during their instruction (item 9) with $\mathrm{M}=3.31$. More importantly, whenever the teachers organized or assigned a task to the students, they often explained the purposes and significance of the task or project (item 10) with $\mathrm{M}=3.80$. By doing so, the teachers could motivate the students to do the task. In addition, one of the teachers' roles is facilitating the process of learning. The finding revealed that the teachers often provided clear instructions of the tasks assigned to them (item 11) with $\mathrm{M}=3.89$, which might help them easily to complete the assigned task. In addition, the teachers often arranged the class and asked the students to work with their classmates (item 12) with $\mathrm{M}=3.91$. By doing so, the teachers could create an autonomous learning environment in which the students could manifest their independence and capacity. To promote learning, giving feedback to the students in a positive and supportive way is one of the motivational strategies. The finding revealed that most of the teachers often did this task (item 13) with $\mathrm{M}=3.63$. More interestingly, "teachers create opportunities for the students to bring into play their capacity in class." obtained the highest frequency (item 14) with $\mathrm{M}=4.24$. Obviously, the teachers wanted their students to be more involved in self-study and encouraged them to make decisions themselves so that they would depend less on the teachers' control. The two items which obtained the lowest frequency are in terms of teachers' making conversations 
with the students to find solutions to learning difficulties and identifying problems that hinder the students' progress (items 15 \& 16) with $\mathrm{M}=3.29 \& 3.21$ respectively. The findings revealed that the teachers sometimes did these tasks.

Finally, learning assessment also received attention from the teachers in their classes. Most of the students agreed that their teachers often used different techniques for assessing their learning (item 17) with $\mathrm{M}=3.97$. It is evident that the teachers believed that the students could do self-assessment and were responsible for their learning.

The data collected from interviews also revealed similar findings. $80 \%$ of the interviewed students reported that the teachers employed different games and learning activities in class. They were asked to work in pairs or sometimes in groups in learning English skills. Particularly, the finding revealed that whenever they had an assignment or a project, the teachers gave clear instructions and deadlines to them, which helped them know how to do the assignment and when to complete or return it. For example:

Several students said, "My speaking teacher usually organizes games in class, but some are just for fun. I enjoy a lot. Of course, we also work in pairs or groups in learning writing. We crosscheck our writing (S2); or "My teachers usually give clear instructions and explain the purpose of the assignment to us. I think the teachers want us to do the assignment well and motivate us in learning (S7)."

However, one issue emerged during the time when the students worked in pairs or in groups. According to $20 \%$ of the interviewed students, some students in their classes used Vietnamese when they discussed a topic in groups. For example:
S10 reported, "The teachers sometimes organized games or a small number of activities. Games are just for fun. When we work in groups some students use Vietnamese to discuss."

Concerning creating opportunities for the students to manifest their capacity, all the students reported that they had chances to use English in class; they made presentations in groups; did some assignments together, tested writing exercises, talked in front of the class, did assignments at home and together with the teachers corrected their assignments. For example:

S6 expressed, "In my class, the students have many chances to use English. The teacher always encourages us to learn English. We do oral and written activities. We prepare presentations at home and in class we take turn to talk in front of the class. My teachers are helpful."

The findings of the interviews also revealed that the teachers sometimes talked to their students both inside and outside the class. They got support from their teachers when they faced difficulties. The teachers sometimes shared learning experience with them; advised them to enhance English level; pointed out their weaknesses and strengths; helped them to solve difficulties; and discussed what difficulties they might face in learning. For example:

S9 reported, "My teachers sometimes spend time talking to students. When I do not understand something, I can ask them for explanation, or when I have difficulty in searching materials, they give me some suggestions and advice. My speaking teacher sometimes shows me how to practice pronunciation at home, or what CDs I should buy." 
Table 2: Practices through in-class activities

\begin{tabular}{|c|c|c|c|}
\hline \multirow[t]{2}{*}{ No. } & \multirow[t]{2}{*}{ Items } & \multicolumn{2}{|c|}{$\mathrm{N}=160$} \\
\hline & & M & St. D \\
\hline 9 & $\begin{array}{l}\text { Your teachers organize various kinds of in-class tasks or activities } \\
\text { for students. }\end{array}$ & 3.31 & 1.161 \\
\hline 10 & $\begin{array}{l}\text { Your teachers explain the purposes and the significance of the } \\
\text { tasks or projects assigned to you. }\end{array}$ & 3.80 & .937 \\
\hline 11 & $\begin{array}{l}\text { Your teachers provide clear instructions of the tasks or projects } \\
\text { assigned to you. }\end{array}$ & 3.89 & .911 \\
\hline 12 & Your teachers ask you to work with your classmates in class. & 3.91 & .970 \\
\hline 13 & Your teachers give feedback in a positive and supportive way. & 3.63 & .958 \\
\hline 14 & $\begin{array}{l}\text { Your teachers create opportunities for you to bring into play your } \\
\text { capacity in class. }\end{array}$ & 4.24 & .942 \\
\hline 15 & $\begin{array}{l}\text { Your teachers make conversations with you to find solutions to } \\
\text { your learning difficulties. }\end{array}$ & 3.29 & 1.013 \\
\hline 16 & $\begin{array}{c}\text { Your teachers identify and show problems that hinder your } \\
\text { progress. }\end{array}$ & 3.21 & 1.107 \\
\hline 17 & $\begin{array}{l}\text { Your teachers assess your learning through the use of different } \\
\text { techniques, e.g. peer-assessment. }\end{array}$ & 3.97 & .871 \\
\hline
\end{tabular}

The findings of the study showed that most of the teachers were autonomous. They had a strong sense of their responsibility for their teaching. Benson (2008) stated that autonomy is a capacity that can be developed in the classroom. Therefore, it can be confirmed that what the English teachers did in their classes, for example, using different strategies to get students involved in the learning process, or organizing the class in a way that motivated students to learn, may contribute to LA development. The findings also implied that the English teachers really wanted to train their students to develop their own learning strategies so that they would not depend on them. They acted as a facilitator to motivate the students, helped them to overcome difficulties and were able to raise the students' awareness of their responsibility. It is evident that the English teachers helped the students to acquire skills and knowledge which they needed to complete the assignments such as organizing the class, identifying objectives or evaluating themselves. In the Vietnamese context, it is not often for a student to initiate a conversation with the teacher about their learning problems. It might be because of oriental culture. Therefore, it is the teacher's responsibility to initiate a dialogue with any student in class (Cotterall \& Crabbe, 2008). The findings of the study revealed that both the teachers and students had conversations. The students themselves could raise their voice in the learning process. They might express their difficulty in learning and want advice on what to do about it.

It can be concluded that the EFL teachers at HUTECH actually used practices through responsibility-informing activities and inclass activities to foster LA in English language learning. The findings of the study implied that the teachers were autonomous and responsible for their teaching. Most of them, more or less, implemented different 
strategies to train the first-year English students to become autonomous. These students needed their teachers' support so that they may successfully continue their study in the coming years.

\subsection{Challenges Encountered by Teachers in Fostering $L A$}

\subsubsection{Student-related challenges}

Regarding challenges related to the students, the data displayed in Table 5 shows that nearly all the English teachers who taught the first-year English majored students had similar perceptions. Put it specifically, eleven out of twelve teachers $(92 \%)$ agreed that first-year students lacked the knowledge and skills for becoming autonomous learners (item 1) with $\mathrm{M}=3.25$ and nine teachers $(75 \%)$ agreed that they were not very motivated in learning English (item 2) with $M=2.83$. Similarly, eleven teachers (92\%) also thought that the students always relied on the teachers' instructions and decisions (item 3) with $M=3.25$. It can be said that the first-year students certainly needed the teacher to show them what to learn in class and teach them how to learn. The students could have access to English through many sources such as foreigners, mass media, and social network. One more issue is that $92 \%$ of the teachers agreed that the students only wanted to pass the exam with high grades (item 5) with $\mathrm{M}=3.08$. Possibly, this element of external motivation was rather high among the students. Especially, all the teachers $(100 \%)$ agreed that the students' proficiency in English was not very high (item 6) with $\mathrm{M}=3.50$. However, in the area of modern technology, not many teachers (42\%) thought that the students did not have many opportunities to use English outside the classroom (item 4) with $M=2.42$. That is to say, most of them thought that the students may access different sources to enhance their English learning.

Responses of the teachers in the interviews revealed that the teachers might encounter challenges caused by the students themselves. All of the three teachers expressed that the firstyear English majored students' low level of proficiency prevented them from implementing strategies in their teaching. In addition, motivation was also a concern. According to them, many students were not motivated. They came to class regularly, possibly because they wanted to pass the exam only. Even, about $10 \%$ of the students in their classes rarely came to class. They only came when the teacher gave mini tests. For example:

T1 said, "About half of the students in my class are responsible for their learning. They come to class regularly and take part in learning activities. They come to class with completed assignments, but the remaining students study not very well. Several of them rarely come to class or do their homework. It seems that they are demotivated. I think they may have part-time jobs without spending time studying."

Responses of the students in the interviews mostly reflected what the teachers expressed about the students' low proficiency level and lack of knowledge and skills of autonomy. Among ten interviewed students, seven of them reported that they were not confident in communication with foreigners or classmates because of their limited vocabulary and shy characteristic. For example:

S5 reported, "My motivation for learning English is studying abroad or finding a good job. However, I rarely speak English in class or to foreigners. Usually, I feel shy and embarrassed. Whenever I want to say something, it is difficult to find vocabulary or ideas." 
Table 5. Student-related challenges encountered by teachers in fostering LA

\begin{tabular}{|c|c|c|c|}
\hline \multirow[t]{2}{*}{ No } & \multirow[t]{2}{*}{ Items } & \multicolumn{2}{|c|}{$\mathrm{N}=12$} \\
\hline & & $\mathbf{M}$ & St.D \\
\hline 1 & $\begin{array}{c}\text { Your students lack the knowledge and skills for becoming autonomous } \\
\text { learners. }\end{array}$ & 3.25 & .622 \\
\hline 2 & Your students are not very motivated in learning English. & 2.83 & .577 \\
\hline 3 & Your students always rely on the teachers' instructions and decisions. & 3.25 & .622 \\
\hline 4 & $\begin{array}{l}\text { Your students do not have many opportunities to use English outside } \\
\text { class. }\end{array}$ & 2.42 & .793 \\
\hline 5 & Your students only want to pass the exam with high grades. & 3.08 & .515 \\
\hline 6 & Your students' proficiency in English is not very high. & 3.50 & .522 \\
\hline
\end{tabular}

Based on the above-presented data, it can be concluded that the findings of the questionnaire are consistent with those of the interviews that revealed that the teachers encountered student-related challenges. The findings showed that the first-year students lacked knowledge and skills for autonomous learning, and that students' low level of motivation and English proficiency may cause challenges to the teachers. It is an undeniable fact because according to Ramos (2006), in language learning, students' motivation and level of language proficiency are linked to the presence and degree of achievable autonomy. That is why the students might always depend on the teachers' instruction. The students' dependence might be closely related to lack of interest in developing LA. That is because they simply might not think it was important, or they might lack the necessary independent learning skills (Reinders \& Lazaro, 2011). However, autonomy is seen as a product of instruction rather than as something which students are currently ready to exercise directly, and autonomy is not a synonym for self-instruction and limited to learning without a teacher (Benson, 2008). Therefore, for the first-year students, they certainly need teachers' support in learning both within and outside class. Learning strategies should be trained; and awareness and responsibilities need to be educated through classroom practices.

\subsubsection{Teacher-related challenges}

Regarding teacher-related challenges, the data displayed in Table 6 shows that very few of the teachers who taught the first-year students encountered the challenges related to themselves. More specifically, only five out of twelve teachers (42\%) agreed that they lacked the necessary strategies to foster LA (item 7) with $\mathrm{M}=2.33$. Especially, only one out of twelve teachers $(8 \%)$ thought that the teachers were not autonomous in teaching (item 8) with $\mathrm{M}=1.75$ and were not good at pedagogical knowledge about learning strategies training (item 9) with $\mathrm{M}=1.83$.

Among the three individual interviews, two teachers expressed that the English teachers were autonomous. They were responsible for their students' learning. In class, they used different strategies to promote the students' awareness of learning both inside and outside class. Nonetheless, one teacher had contrary perceptions. He reported,

"When I was at university more than 20 years ago, I learned how and what to teach. No teachers mentioned how to train students. Now I try to encourage my students but it does not work. Many students never learn. They never do grammar or vocabulary exercises at home. I think they are not autonomous. It is the fault of the teacher (T3)." 
Obviously, this teacher thought that he might lack pedagogical knowledge about learning strategies training or he might not know how to create a highly effective learning environment.

Table 6. Teacher-related challenges encountered by teachers in fostering LA

\begin{tabular}{|c|c|c|c|}
\hline No & Items & \multicolumn{2}{|c|}{$\mathbf{N = 1 2}$} \\
\cline { 3 - 4 } & Teachers lack the necessary strategies to foster learner autonomy. & 2.33 & .651 \\
\hline 7 & Teachers themselves are not autonomous in teaching. & 1.75 & .754 \\
\hline 8 & $\begin{array}{c}\text { Seachers are not very good at pedagogical knowledge about learning } \\
\text { strategies training. }\end{array}$ & 1.83 & .577 \\
\hline 9 & \begin{tabular}{c} 
The \\
\cline { 3 - 4 }
\end{tabular} &
\end{tabular}

The findings of the study revealed that most of the teachers who taught the firstyear students thought they were autonomous teachers. They understood pedagogical knowledge of learning strategies training and promoted autonomous learning in their classes. Teachers' awareness and knowledge of learning strategies may help foster LA. Those are metacognitive strategies which help students think about their learning such as planning, monitoring and evaluating; cognitive strategies which provide students with the ability to use materials; and socioaffective strategies which help students develop skills for cooperating with others and for creating a positive learning environment (Murray \& Christison, 2011). The first-year students may lack those strategies, so they need support from their teachers. Any teacher who is unaware of those strategies may encounter challenges in fostering LA.

\subsubsection{Context-related challenges}

Regarding context-related challenges, the data displayed in Table 7 shows that among six factors that may hinder teachers from fostering LA, three of them obtained agreement from the teachers. More specifically, 67\% teachers agreed that in-service professional development workshops on autonomy had never been provided (item 12) with $\mathrm{M}=2.83$; similarly, $67 \%$ of the teachers thought that there was a shortage of resources or extra materials for both teachers and students (item 14) with $M=2.67$; and $75 \%$ teachers agreed that the weekly allotted time for English modules was limited (item 15) with $\mathrm{M}=2.83$. Regarding technology, $42 \%$ of the teachers thought that it was not sufficiently provided for EFL learning in the context (item 10) with $\mathrm{M}=2.08$; in terms of rules and regulations of the faculty, $25 \%$ of the teachers thought that they hindered teachers' freedom in making choices and decisions on their teaching (item 11) with $\mathrm{M}=2.00$; and finally, $50 \%$ of the teachers thought that prescribed syllabus and materials hindered teachers' creation (item 13) with $\mathrm{M}=2.33$.

The data collected from the three individual interviews also revealed that teachers were not satisfied with several factors that prevented them from fostering LA in their classes. One of the factors that they blamed most was that workshops on how to enhance LA had never been organized in their context. They also blamed that relevant resources for both teachers and students were limited. The content of learning was limited to the prescribed syllabus or some units in one textbook. For example:

$\mathrm{T} 2$ expressed, "I think many factors may affect my teaching. It is not easy to foster the students' autonomy because of the facilities for teaching and learning. Students do not have many reference books for doing more 
exercises at home. It seems that they cannot afford reference books. Most of the time in class is spent on completing what is prescribed in the syllabus for the exam; we usually test what the students learn in the textbook."

Table 7. Context-related challenges encountered by teachers in fostering LA

\begin{tabular}{|c|c|c|c|}
\hline \multirow[t]{2}{*}{ No } & \multirow[t]{2}{*}{ Items } & \multicolumn{2}{|c|}{$\mathrm{N}=12$} \\
\hline & & M & St.D \\
\hline 10 & $\begin{array}{c}\text { Technology is not sufficiently provided for EFL learning in the } \\
\text { context. }\end{array}$ & 2.08 & .900 \\
\hline 11 & $\begin{array}{l}\text { Rules and regulations of the faculty limit teachers' freedom in making } \\
\text { choices and decisions on their instruction. }\end{array}$ & 2.00 & 1.044 \\
\hline 12 & $\begin{array}{l}\text { In-service professional development workshops on autonomy have } \\
\text { never been provided. }\end{array}$ & 2.83 & .937 \\
\hline 13 & Prescribed syllabus and materials hinder teachers' creativity. & 2.33 & .778 \\
\hline 14 & $\begin{array}{l}\text { There is a shortage of extra materials or resources for both teachers } \\
\text { and students. }\end{array}$ & 2.67 & 1.073 \\
\hline 15 & The weekly allotted time for English modules is limited. & 2.83 & .577 \\
\hline
\end{tabular}

The findings of the study showed that the teachers in the context encountered several challenges related to the context, namely limited allotted time in class, resources or extra materials and in-service professional development. Benson (2010) argues that teachers may exercise their capacity to control teaching within multiple constraints such as school rules, textbooks and curricula. However, autonomous teaching requires language teachers to examine the contextual conditions that can facilitate or constrain their professional practices and professional development actions (Benson, 2010). It is implied that the teachers could reflect what their contextual conditions were like. It is tantamount to the fact that most of them were aware of what prevented them from fostering students' autonomy in English learning. It can also be concluded that they were responsible for their teaching as Sehrawat (2014) stated that an autonomous teacher feels personal responsibilities, wants to attend workshops and comes up with new classroom ideas to foster LA. They really wanted to be really autonomous rather than "pseudo-autonomy" as Candy (1991) stated. It is undeniable that teacher autonomy is necessary in order to be able to meet students' needs, interests and motivation (Sehrawat, 2014) even though teachers may confront low-resource challenges, limited learning time, or other context-related challenges.

In conclusion, the findings of the study revealed that the teachers who taught firstyear English majored students in the context encountered several challenges in fostering students' autonomy in English learning. The findings of the current study are in line with those discovered by Borg and Al-Busaidi (2012); Urun, Demir, and Akar (2014), and Alibakhshi (2015) in their studies that reported that English teachers might encounter studentrelated, teacher-related and context-related challenges in fostering LA.

\section{Conclusions and recommendations}

The current study aims to explore students' perceptions of their teachers' practices used in fostering LA and teachers' perceptions of the challenges they may encounter in fostering LA 
for the first-year English majored students at HUTECH. The findings allow the researcher conclude that the English teachers, more or less, have used both practices through responsibility-informing activities and in-class activities to foster LA. It is evident that from students' perspectives, most of the English teachers are autonomous and promote LA in their classes. They are responsible for their teaching and students' learning. Nonetheless, according to them, several challenges may hinder their desire to foster LA. The most serious challenges are related to the students because many of them are not motivated, they still want to rely on teachers and they have low level of English proficiency. It is undeniable that many students lack autonomy. They are not much aware of their learning process. The findings of the study imply that first-year English students may be in their shifting process from a teachercentered English classroom which might exist in high school to a student-centered English classroom which is being implemented at university. Some of them are still not ready in becoming autonomous students. They are motivated to learn English; however, they are first-year students so they may lack knowledge and skills for assuming autonomy. That is why they need teachers' support in training learning strategies and developing LA.

Based on the findings of the study, it is therefore recommended that, firstly course designers should provide extra materials or reference books relating to the module for both teachers and students. They should give more detailed descriptions of the requirements for the teachers in their instruction. Some teachers may need knowledge and skills of fostering LA; it is suggested that in-service professional development workshops on LA and TA be organized for the teachers. Secondly, English teachers should work together with students to reduce obstacles which prevent them from fostering LA in their classes. The first-year students may lack knowledge and skills of LA and student-centered paradigm may be still strange to them; it is the teachers' responsibility to train them how to learn both inside and outside class. Teachers should be aware of different roles such as facilitators, gap-fillers, advisors and promoters that they may act during their instruction, not arbitrators anymore. Teachers should know what strategies can be used to foster students' in-class learning and out-of-class learning and help students to integrate both of these domains. Finally, for the first-year English majored students, having motivations for learning English may still be insufficient to assure that they are autonomous students. They should be aware of the learning process and learning strategies, gradually develop the ability to function independently and reduce their dependence on teachers.

As the current study was conducted in only one specific site with the focus on firstyear English majored students, its findings may not be generalizable to other sites and more advanced students.

Other studies are recommended to replicate the same study with similar variables concerning first-year non-English majored students or in other universities with more advanced students.

\section{References}

Agustín-Llach, M. P. \& Alonso, A. C. (2017). Fostering learner autonomy through vocabulary strategy training. In M. Pawlak, A. Mystkowska-Wiertelak \& J. Bielak (Eds.). Autonomy in second language learning: Managing the resources (pp. 141-158). Cham, Switzerland: Springer.

Alibakhshi, G. (2015). Challenges in promoting EFL learners' autonomy: Iranian EFL teachers' perspectives. Issues in Language Teaching (ILT), 4-(1), 79-98. 
Benson, P. (2008). Teachers' and learners' perspectives on autonomy. In T. Lamb \& H. Reinders (Eds.), Learner and teacher autonomy: Concepts, realities, and responses (pp. 16-32). Amsterdam: John Benjamins Publishing Co.

Benson, P. (2010). Teacher education and teacher autonomy: Creating spaces for experimentation in secondary school English language teaching. Language Teaching Research, 14-(3), 259-275.

Benson, P. (2011). Teaching and researching autonomy ( $2^{\text {nd }}$ ed.). London: Pearson.

Borg, S., Al-Busaidi, S. (2012). Learner autonomy: English language teachers' beliefs and practices. British Council: ELT research paper 12-07.

Brown, H. D. (2002). Strategies for success: A practical guide to learning English. New York: Longman.

Candy, P. C. (1991). Self-direction for lifelong learning: A comprehensive guide to theory and practice. San Francisco, CA: Jossey-Bass.

Chik, A. (2018). Learner autonomy and digital practices. In A. Chik, N. Aoki, \& R. Smith (Eds.), Autonomy in language learning and teaching (pp.73-92). London: Macmilan Publishers Ltd.

Cotterall,, S. \& Crabbe, D. (2008). Learners talking: From problem to solution. In T. Lamb \& H. Reinders (Eds.), Learner and teacher autonomy (pp.125140). Amsterdam: John Benjamins Publishing Co.

Dam, L. (2003). Developing learner autonomy: The teacher's responsibility. In D. Little, J. Riddley, \& E. Ushioda (Eds.), Learner autonomy in the foreign language classroom: Teacher, learner, curriculum and assessment (pp. 135-146). Dublin: Authentic.

Dang, T. T. (2012). Learner Autonomy Perception and Performance: A study on Vietnamese students in online and offline learning environments. Unpublished Ph.D. thesis, La Trobe University.

Dikilitaş, K \& Griffiths, C. (2017). Developing language teacher autonomy through action research. Istanbul: Palgrave Macmillan

Esch, E. M. (1997). Learner training for autonomous language learning. In C. N. Candlin (Ed.), Autonomy and independence in language learning (pp.164175). New York: Longman.

Feryok, A. (2013). Teaching for learner autonomy: the teacher's role and sociocultural theory. Innovation in Language Learning and Teaching, 7-(3), 213-225.

Ganza, W. L. (2008). Learner autonomy-teacher autonomy: Interrelating and the will to empower. In T. Lamb \& H. Reinders (Eds.), Learner and teacher autonomy (pp. 63-78). Amsterdam: John Benjamins Publishing Co.
Holec, H. (1981). Autonomy in foreign language leaerning. Oxford: Pergamon.

Jing, H. (2007). Teacher autonomy in second language education. CELEA Journal, 30-(1), 30-42.

Klimas, A. (2017). A goal-setting logbook as an instrument fostering learner autonomy. In $\mathrm{M}$. Pawlak, A. Mystkowska-Wiertelak \& J. Bielak (Eds.). Autonomy in second language learning: Managing the resources (pp. 21-33). Cham, Switzerland: Springer.

Lamb, T. (2008). Learner and teacher autonomy. In T. Lamb \& H. Reinders (Eds.), Learner and teacher autonomy: Concepts, realities, and responses (pp. 269-284). Amsterdam: John Benjamins Publishing Co.

Le, T. N. A. (2018). EFL students' voices on learner autonomy at a university in the Mekong Delta. $V N U$ Journal of Foreign Studies, 34-(2), 26-38.

Le, X.Q.(2013).Fostering learner autonomy in language learning in tertiary education: An intervention study of university students in Hochiminh city, Vietnam. Unpublished Ph.D. thesis, Nottingham University.

Ling, L. (2007). Fostering teacher autonomy in the use of English teaching materials. CELEA Journal, 30 (1), 96-102.

Little, D. (1995). Learning as dialogue: The dependence of learner autonomy on teacher autonomy. System, 23-(2), 175-181.

Little, D. (1999). Developing learner autonomy in the foreign language classroom: A social-interactive view of learning and three fundamental pedagogical principles. Revista Canaria de Estudios Ingleses, 38, 77-88.

Little, D. (2004). Constructing a theory of learner autonomy: Some steps along the way. In K. Mäkinen, P. Kaikkonen, \& V. Kohonen (Eds.), Future perspectives in foreign language education (pp. 15-25). Oulu: Oulu University Press.

Locke, E.A. 1996. Motivation through conscious goal setting. Applied and Preventive Psychology 5, 117 124.

Macaro, E. (2008). The shifting dimensions of language learner autonomy. In T. Lamb \& H. Reinders (Eds.) Learner and teacher autonomy: Concepts, realities, and responses (pp. 47-62). Amsterdam: John Benjamins Publishing Co.

Murray, D. E. \& Christison, M. (2011). What English language teachers need to know (Volume I): Understanding Learning. New York: Routledge.

Nguyen, T. C. L. (2009). Learner autonomy and EFL learning at the tertiary level in Vietnam. Unpublished 
doctoral thesis. Victoria University of Wellington. Retrieved http://researcharchive.vuw.ac.nz.

Nguyen, T. N. (2014). Learner Autonomy in Language Learning: Teachers' belief. Ph.D. Thesis, Queensland University of Technology.

Nunan, D. (1997). Designing and adapting materials to encourage learner autonomy. In C. N. Candlin (Ed.), Autonomy and independence in language learning (pp.192-203). New York: Longman.

Palfreyman. M. D. (2018). Learner autonomy and groups. In A. Chik, N. Aoki, \& R. Smith (Eds.), Autonomy in language learning and teaching (pp.51-72). London: Macmilan Publishers Ltd.

Pearson, L. C. \& W. Moomaw. W. (2005). The relationship between teacher autonomy and stress, work satisfaction, empowerment and professionalism. Education Research Quarterly, 29(1), 37-53.

Ramos, R. C. (2006). Considerations on the role of teacher autonomy. Colombian Applied Linguistics Journal, 8 (Sept 2006), 184-202.

Reinders, H. \& Lewis, M. (2008). Materials evaluation and teacher autonomy. In T. Lamb \& H. Reinders (Eds.), Learner and teacher autonomy (pp.205215). Amsterdam: John Benjamins Publishing Co.

Reinders, H., \& Lazaro, N. (2011). Beliefs, identity and motivation in implementing autonomy: The teachers' perspective. In G. Murray, X. Gao \& T. Lamb (Eds.), Identity, motivation, and autonomy in language learning (pp.125-142). Bristol: Multilingual Matters.

Sehrawat, J. (2014). Teacher autonomy: Key to teaching success. International Journal of Research and Education, 4-(1), 1-8.

Sheerin, S. (1997). An exploration of the relationship between self-access and independent learning. In C. N. Candlin (Ed.), Autonomy and independence in language learning (pp.54-65). New York: Longman.

Sinclair, B. (2008). Multiple voices: Negotiating pathways towards teacher and learner autonomy. In T. Lamb \& H. Reinders (Eds.), Learner and teacher autonomy (pp.237-259). Amsterdam: John Benjamins Publishing Co.

Smith, R., Kuchah, K. \& Lamb, M. (2018). Learner autonomy in developing countries. In A. Chik, N. Aoki, \& R. Smith (Eds.), Autonomy in language learning and teaching (pp.7-26). London: Macmilan Publishers Ltd.

Teng, F. (2019). Autonomy, agency, and identity in teaching and learning English as a foreign language. Singapore: Springer.

Thavenius, C. (1999). Teacher autonomy for learner autonomy. In S. Cotterall \& D. Crabbe (Eds.). Leamer autonomy in language learning: Defining the field and effecting change (pp.159-163). New York: Peter Lang GmbH.

Tran, T. Q. \& Duong, T. M. (2018). EFL learners' perceptions of factors influencing learner autonomy development. Kasetsart Journal of Social Sciences, 1-6. Retrieved from https://doi.org/10.1016/j.kjss.

Trinh, Q. L. (2005). Stimulating learner autonomy in English language education: A curriculum innovation study in a Vietnamese context. Ph.D. Thesis. University of Amsterdam, Amsterdam.

Urun, M. F., Demir, C. E. \& Akar, H. (2014). A study on ELT high school teachers' practices to foster learner autonomy. Journal of Language Teaching and Research, 5-(4), 825-836.

Vázquez, B. M. (2016). Teacher development for autonomy: an exploratory review of language teacher education for learner and teacher autonomy. Innovation in Language Learning and Teaching, 12(4), 387-398.

Wiśniewska, H. (2017). Learner Autonomy: The role of educational materials in fostering self-evaluation. In M. Pawlak, A. Mystkowska-Wiertelak \& J. Bielak (Eds.). Autonomy in second language learning: Managing the resources (pp. 85-98). Cham, Switzerland: Springer.

Xu, L. (2015). A study on college English teachers' role in developing learner autonomy. Theory and Practice in Language Studies, 5-(2), 435-441.

Yan, H. (2010). A brief analysis of teacher autonomy in second language acquisition. Journal of Language Teaching and Research, 1-(2), 175-176. 


\title{
TÍNH TỰ CHỦ CỦA SINH VIÊN: NHŨ̃NG BIỆN PHÁP GIÁO VIÊN TIẾNG ANH SỬ DỤNG VÀ NHỮNG THÁCH THỨC HỌ GẶP TRONG VIỆC THÚC ĐẨY TÍNH TỰ CHỦ CỦA SINH VIÊN ĐẠI HỌC
}

\author{
Lê Văn Tuyên, Huỳnh Thị An \\ Trường Đại Học Công Nghệ TP. HCM (HUTECH) \\ 475 A Điện Biên Phủ, Bình Thạn, Thành phố Hồ Chi Minh, Việt Nam
}

Tóm tắt: Tính tự chủ của giáo viên và sinh viên chắc chắn được cho là một trong các yếu tố có ảnh hưởng tới hiệu quả của việc dạy và học tiếng Anh trong môi trường tiếng Anh không phải là tiếng mẹ đẻ như ở Việt Nam. Tìm hiểu nhận thức của giáo viên và sinh viên đối với yếu tố này được xem như là một đóng góp có giá trị cho lĩnh vực dạy và học ngoại ngữ. Vì thế mục đích của đề tài là tìm hiểu nhận thức của sinh viên về những phương thức mà giáo viên áp dụng và nhận thức của giáo viên về những thách thức mà họ gặp trong quá trình hỗ trợ sinh viên trường Đại học Công nghệ Thành phố Hồ Chí Minh (HUTECH) nâng cao tính tự chủ trong học tập. Công cụ sử dụng để thu thập dữ liệu cho nghiên cứu là bảng câu hỏi khảo sát và phỏng vấn. Đối tượng nghiên cứu là 12 giáo viên tiếng Anh và 160 sinh viên năm thứ nhất ngành Ngôn ngữ Anh. Kết quả của nghiên cứu cho thấy hầu hết giáo viên đã có những biện pháp khơi dậy trách nhiệm của sinh viên đối với tinh thần tự chủ trong học tập thông qua các hoạt động hỗ trợ trong giờ học. Kết quả cũng chỉ ra một số thách thức mà giáo viên thường gặp trong quá trình hỗ trợ sinh viên có liên quan tới sinh viên, giáo viên và môi trường học tập. Nghiên cứu này hy vọng sẽ đóng góp vào việc nâng cao hiệu quả dạy và học tiếng Anh tại HUTECH nói riêng và ở bậc đại học Việt Nam nói chung.

Tù̀ khóa: tính tự chủ của giáo viên, tính tự chủ của sinh viên, biện pháp, thách thức, bậc đại học 


\section{APPENDIXES}

\section{APPENDIX A: TEACHER QUESTIONNAIRE}

\section{Challenges encountered by teachers in fostering learner autonomy}

Dear colleagues,

I am Le Van Tuyen from the Faculty of English Language-HUTECH. I would like you to help complete this questionnaire. The aim of this questionnaire is to explore the challenges that you may encounter in the process of fostering your EFL students' autonomy at HUTECH. The data that you provide will not be used for any purpose except for research.

For part 2, could you please CIRCLE 1, 2. 3 or 4 for your answers according to the four scales as follows:

\section{Strongly Disagree (SD) 2. Disagree (D) 3. Agree (A) 4. Strongly Agree (SA)}

Part 1: Demographic information

Gender:

Age:

Years of teaching experience:

Qualifications:
Male

24-29

$2-4$

BA
Female

30-35

$5-7$

MA
36-40 41-over

8-10 11-over

$\mathrm{Ph} . \mathrm{D}$

Part 2: Challenges encountered by teachers

\begin{tabular}{|c|c|c|c|c|c|}
\hline No & Items & $\mathrm{SD}$ & $\mathrm{D}$ & A & SA \\
\hline \multicolumn{6}{|c|}{ Student-related challenges } \\
\hline 1 & $\begin{array}{l}\text { Your students lack the knowledge and skills for becoming } \\
\text { autonomous learners. }\end{array}$ & 1 & 2 & 3 & 4 \\
\hline 2 & Your students are not very motivated in learning English. & 1 & 2 & 3 & 4 \\
\hline 3 & $\begin{array}{l}\text { Your students always rely on the teachers' instruction and } \\
\text { decisions. }\end{array}$ & 1 & 2 & 3 & 4 \\
\hline 4 & $\begin{array}{l}\text { Your students do not have many opportunities to use English } \\
\text { outside the classroom. }\end{array}$ & 1 & 2 & 3 & 4 \\
\hline 5 & Your students only want to pass the exam with high grades. & 1 & 2 & 3 & 4 \\
\hline 6 & Your students' English proficiency is not very high. & 1 & 2 & 3 & 4 \\
\hline \multicolumn{6}{|c|}{ Teacher-related challenges } \\
\hline 7 & $\begin{array}{l}\text { Teachers lack the necessary strategies to foster learner } \\
\text { autonomy. }\end{array}$ & 1 & 2 & 3 & 4 \\
\hline 8 & Teachers themselves are not autonomous in teaching. & 1 & 2 & 3 & 4 \\
\hline 9 & $\begin{array}{l}\text { Teachers are not very good at pedagogical knowledge about } \\
\text { learning strategies training. }\end{array}$ & 1 & 2 & 3 & 4 \\
\hline \multicolumn{6}{|c|}{ Context-related challenges } \\
\hline
\end{tabular}




\begin{tabular}{|c|c|c|c|c|c|}
\hline No & Items & SD & D & A & SA \\
\hline 10 & $\begin{array}{c}\text { Technology is not sufficiently provided for EFL learning in the } \\
\text { context. }\end{array}$ & 1 & 2 & 3 & 4 \\
\hline 11 & $\begin{array}{c}\text { Rules and regulations of the faculty limit teachers' freedom in } \\
\text { making choices and decisions on their instruction. }\end{array}$ & 1 & 2 & 3 & 4 \\
\hline 12 & $\begin{array}{c}\text { In-service professional development workshops on autonomy } \\
\text { have never been provided. }\end{array}$ & 1 & 2 & 3 & 4 \\
\hline 13 & Prescribed syllabus and materials hinder teachers' creation. & 1 & 2 & 3 & 4 \\
\hline 14 & $\begin{array}{c}\text { There is a shortage of extra materials or resources for both } \\
\text { teachers and students. }\end{array}$ & 1 & 2 & 3 & 4 \\
\hline 15 & The weekly allotted time for English modules is limited. & 1 & 2 & 3 & 4 \\
\hline
\end{tabular}

\section{APPENDIX B: STUDENT QUESTIONNAIRE}

Dear students,

This questionnaire is used to explore your perceptions of teachers' practices used to foster your autonomy in learning English. The information you provide will be used for research only. Please CIRCLE 1, 2, 3, 4, or 5 according to the scales as follows:

\section{Never (N)}

\section{Rarely (R)}

3. Sometimes (S)

4. Often (O)

5. Always (A)

\begin{tabular}{|c|c|c|c|c|c|c|}
\hline No & Items & $\mathrm{N}$ & $\mathrm{R}$ & $\mathrm{S}$ & $\mathrm{O}$ & $\mathrm{A}$ \\
\hline 1 & $\begin{array}{c}\text { Your teachers help you to set up your own long-term } \\
\text { and short-term learning objectives. }\end{array}$ & 1 & 2 & 3 & 4 & 5 \\
\hline 2 & $\begin{array}{c}\text { Your teachers encourage you to make plans for } \\
\text { studying. }\end{array}$ & 1 & 2 & 3 & 4 & 5 \\
\hline 3 & $\begin{array}{c}\text { Your teachers tell you the skills and strategies you } \\
\text { need to learn on your own. }\end{array}$ & 1 & 2 & 3 & 4 & 5 \\
\hline 4 & $\begin{array}{c}\text { Your teachers encourage you to read English books, } \\
\text { magazines, and newspapers outside class. }\end{array}$ & 1 & 2 & 3 & 4 & 5 \\
\hline 5 & $\begin{array}{c}\text { Your teachers suggest materials, websites, videos and } \\
\text { other tools that you can use to practice English outside } \\
\text { class. }\end{array}$ & 1 & 2 & 3 & 4 & 5 \\
\hline 6 & $\begin{array}{c}\text { Your teachers encourage you to do assignments or } \\
\text { projects outside class. }\end{array}$ & 1 & 2 & 3 & 4 & 5 \\
\hline 7 & $\begin{array}{c}\text { Your teachers introduce tools and techniques for your } \\
\text { self-assessment. }\end{array}$ & 1 & 2 & 3 & 4 & 5 \\
\hline 8 & $\begin{array}{c}\text { Your teachers show you how to evaluate your own } \\
\text { learning progress. }\end{array}$ & 1 & 2 & 3 & 4 & 5 \\
\hline 9 & $\begin{array}{c}\text { Your teachers organize various kinds of in-class tasks } \\
\text { or activities for students. }\end{array}$ & 1 & 2 & 3 & 4 & 5 \\
\hline 10 & $\begin{array}{c}\text { Your teachers explain the purposes and the significance } \\
\text { of the tasks or projects assigned to you. }\end{array}$ & 1 & 2 & 3 & 4 & 5 \\
\hline
\end{tabular}




\begin{tabular}{|c|c|c|c|c|c|c|}
\hline No & Items & $\mathrm{N}$ & $\mathrm{R}$ & $\mathrm{S}$ & $\mathrm{O}$ & $\mathrm{A}$ \\
\hline 11 & $\begin{array}{c}\text { Your teachers provide clear instructions of the tasks or } \\
\text { projects assigned to you. }\end{array}$ & 1 & 2 & 3 & 4 & 5 \\
\hline 12 & $\begin{array}{c}\text { Your teachers ask you to work with your classmates in } \\
\text { class. }\end{array}$ & 1 & 2 & 3 & 4 & 5 \\
\hline 13 & Your teachers give feedback in a positive and \\
supportive way. & 1 & 2 & 3 & 4 & 5 \\
\hline 14 & $\begin{array}{c}\text { Your teachers create opportunities for you to bring into } \\
\text { play your capacity in class. }\end{array}$ & 1 & 2 & 3 & 4 & 5 \\
\hline 15 & $\begin{array}{c}\text { Your teachers discuss with you to find solutions to } \\
\text { your learning difficulties. }\end{array}$ & 1 & 2 & 3 & 4 & 5 \\
\hline 16 & $\begin{array}{c}\text { Your teachers identify and show problems that hinder } \\
\text { your progress. }\end{array}$ & 1 & 2 & 3 & 4 & 5 \\
\hline 17 & $\begin{array}{c}\text { Your teachers assess your learning through the use of } \\
\text { different techniques, e.g. peer-assessment. }\end{array}$ & 1 & 2 & 3 & 4 & 5 \\
\hline
\end{tabular}

\section{APPENDIX C: STUDENT INTERVIEW QUESTIONS}

1. What are your motivations for learning English?

2. At what English proficiency level do you think you are?

3. What do you do to improve your English inside and outside class?

4. What do your English teachers usually do to develop students' autonomy? (For example help you set up plan and objectives for learning, create opportunities for all the students to use English, a dynamic and interesting learning environment in class, use different strategies, organize pair work or group work, and organize games or activities for the students to practice English, show you how to evaluate your learning).

5. Do your teachers encourage you to study outside class? For example, do they introduce books, websites; or ask you to prepare lessons or presentations.....?

6. Do your teachers sometimes spend time talking to you about your learning, or sharing ideas about learning with you, or telling you what problems may hinder your learning?

\section{APPENDIX D: TEACHER INTERVIEW QUESTIONS}

1. What do you think about the first-year English majored students' level of autonomy in learning E?

2. What do you usually do to foster learner autonomy in your class?

3. What challenges have you encountered do you think you may encounter in fostering learner autonomy? 